\title{
WATER CONCEPT IN THE NOVEL BY OLENA PECHORNA THE WITCH
}

\section{Gurduz Andriy}

Candidate of Sciences in Philology, Associate Professor

ORCID ID 0000-0001-8474-3773

Mykolaiv V.O. Sukhomlynskyi National University

24, Nikolska Str., Mykolaiv, 54030, Ukraine

gurdai@ukr.net

In Ukrainian prose of the first decades of the XXI century nearly greatest attention to the artistic word cleanness is spared by Olena Pechorna, her scantily explored novels deserve a system study. The novel The Witch occupies an important place in her artistic work and it is organic for her idiostyle paradigm, but while did not get a professional estimation. In our article we carry out an attempt to define the specific of dominant water concept in the novel The Witch for the first time. The key in the article become the study of the realization type of the water concept of in the book, and also the research of changes of its expression by comparison to the previous novels of authoress, finding out of method of subordination of The Witch poetics to the named concept. In the article are used psychoanalytic, system and comparable methods of research, elements of corporealmimetic method. The Witch continues a row of pseudomystic novels, where the expressed corporalness and system personification of the natural phenomena, objects, abstractions, etc. assists to the irrational atmosphere.

Personification here is more electoral, its receptions are carried in descriptions of the emotional state, landscape, interior. "Circular elements" go out on the first plan and they assists to conceptualization of the different phenomena row. That are leit-motif imitations: updating; elements of application of meal and / whether taste feelings; the anatomy-type description of the phenomena, objects, abstractions, etc.; expressed corporalness.

In The Witch system of images and microimages a separate place belongs to the water concept. As well as in "The Circles on the Water» or "A Fortress for the Heart», a water is living here, but already not anatomic and it is more frequent represented in description of processes and states. The accordingly executed descriptions of personages experiencing and properties complement a water dictate in the novel. The dominating woman beginning, incident to the pantheistic picture of the authoress' art world, is underlined by the dominant role of water element and by proper key concept.

This concept is realized through variant poetics and subordinates the work structure, co-operates with the analogical clusters of personification, leit-motif imitations, with the concepts of memory, returning, paradise, hell, etc. The named water concept also assists in forming in the novel of the mosaic mythopoetic paradigm. The concepts of memory, «winged» woman are actualized in the novel.

Key words: concept, image, water, personification, motif, corporalness.

\section{КОНЦЕПТ ВОДИ В РОМАНІ ОЛЕНИ ПЕЧОРНОЇ «ХИМЕРНИЦЯ»}

\section{Гурдуз Андрій}

Кандидат філологічних наук, доцент

ORCID ID 0000-0001-8474-3773

Миколаївський національний університет

імені В. О. Сухомлинського

вул. Нікольська, 24, Миколаїв, 54000, Україна

gurdai@ukr.net

(C) Gurduz A., 2020 
В украӥнській прозі перших десятиліть XXI cm. чи не найбільшу увагу чистоті художнього слова приділяє Олена Печорна, малодосліджена романістика якої заслуговує на системне вивчення. Роман «Химерниця» займає важливе місие в ї̈ доробку й органічний парадигматиці ї̈ ідіостилю, але поки не отримав фахової оцінки. Уперше здійснюємо спробу визначити специфіку домінантного в романі «Химерниця» концепту води. Ключовими в розвідиі стають висвітлення характеру реалізації концепту води в книзі $і$ простеження змін його вираження порівняно $з$ попередніми романами письменниці, з'ясування способу підпорядкованості поетики «Химерниці» названому концепту. У процесі роботи використані психоаналітичний, системний $i$ зіставний методи дослідження, елементи тілесно-міметичного методу.«Химерницею» продовжено ряд квазімістичних романів, де атмосфері ірраціонального сприяють виражена тілесність $і$ системне уособлення природних явищ, об'єктів, абстракцій тощо. Уособлення тут вибірковіше, його прийоми перенесені в описи душевного стану, пейзажу, інтер'єру. На перший план виходять «кільцеві елементи», які сприяють концептуалізації низки явищ. Це лейтмотивні імітацї: оновлення; елементів уживання їжі та / чи смакових відчуттів; анатомізації явищ, предметів, абстракцій тощо; підкресленої тактильності.

У персоналізованій системі образів і мікрообразів «Химерниці» окреме місие належить кониепту води. Як $і$ в «Колах на воді» чи «Фортеиі для серия», вода жива, але вже не анатомізована $i$ частіше змальовувана в описі процесів $i$ станів. Доповнюють водний диктат відповідно оформлені описи пережсивнь $i$ властивостей персонажів. Панівне жіноче начало, властиве пантеїстичній картині світу письменниці, підкреслено домінантністю стихії води й відповідним ключовим концептом. Він реалізується через варіативну поетику і підпорядковує структуру твору, взаємодіє з аналогічними кластерами уособлення, лейтмотивними імітаціями, з концептами пам'яті, повернення, раю, пекла ци под., сприяючи формуванню в романі міфопоетичної парадигми мозайчного типу. Актуалізовані в романі концепти пам'яті, «крилатої» жінки.

Ключові слова: конщепт, образ, вода, уособлення, мотив, тілесність.

Вступ. Категорія продуктивності митця в сучасному світі зазнає значного переосмислення, причому в критиці, масовій культурі на перший план часто виходить кількісний показник поповнення художнього доробку. Останнє пов'язане 3 тенденціями зближення мистецтва 3 розважальною індустрією й здатне викликати інфляцію художності в сенсі унікальності, коли невиправдане розширення допустимих меж запозичення маскується під явища нових «мистецьких» технік. В українській прозі перших десятиліть XXI ст. чи не найбільшу увагу до чистоти художнього слова виявляє Олена Печорна, романістика якої посідає помітне місце в національному літературному процесі, хоча малодосліджена (контекстно деякі твори проходять у розвідках Г. Швець, О. Архіпової, Н. Герасименко) й заслуговує на системне вивчення, започатковане нами в попередніх студіях [зокрема, див.: $2 ; 4 ; 5]$. Крім того, авторка перебуває в силовому полі мистецького канону М. Коцюбинського [4, с. 165], формуючи пов'язану з його наративною логікою прозописьма відповідну стратегію [7, с. 533]. Останнє як феномен становить окремий науковий інтерес, адже дослідження «школи» великого Сонцепоклонника охоплює літературний процес по 1990-ті pp. [7,340-528], і введення в цю площину нового матеріалу принципово важливе для вивчення системності розвитку української літератури.

Роман «Химерниця» 2020 р. органічний парадигматиці ідіостилю Олени Печорної, подібно до їі попередніх книг, характеризується міфопоетикою мозаїчного типу й $€$ самобутнім на цьому рівні організації порівняно 3 масивом жіночої романістики початку XXI ст. (аспектно ж - як і в випадку з «Фортецею для серця»його сюжетна оригінальність полемічна: щодо лінії потрапляння в ліс мешканців міста й лікування їх усамітненою таємничою жінкою). У доробку мисткині 
«Химерниця» займає важливе місце, але - в силу новизни - поки не отримала комплексної фахової оцінки.

Мета роботи У пропонованій статті, виконуваній у руслі актуальної проблематики, вперше здійснюємо спробу визначити специфіку домінантного в романі «Химерниця» концепту води. Ключовими в розвідці стають а) висвітлення характеру реалізації концепту води в книзі і простеження змін його текстуального вираження порівняно 3 попередніми романами письменниці, які формують своєрідний метатекст, і б) з'ясування різнорівневої підпорядкованості поетики «Химерниці» концепту води.

Об'скт - роман Олени Печорної «Химерниця».

Предмет - специфіка вираження в названому романі Олени Печорної концепту води в системній взаємодії тематичних кластерів уособлення й деяких інших концептів.

У процесі виконання роботи використані наступні методи дослідження: психоаналітичний (застосований, зокрема, під час аналізу способу художнього вираження домінантного в «Химерниці» жіночого начала - концепту води, супровідних концептів і мотивів та їх взаємодії; у трактуванні в тексті семантичного навантаження тематично споріднених кластерів уособлення тощо), системний i зіставний («Химерниця» аналізована в системі романістики Олени Печорної як ланка iii метапрози), елементи тілесно-міметичного методу (в інтерпретації типів уособлення в романі, зокрема анатомізації явищ природи й ряду об'єктів; підкресленої тактильності, тілесності загалом, концепту крилатості в зображенні сучасної жінки).

Виклад основного матеріалу. Системний аналіз прози Олени Печорної 2010 2020 pp. - від психоаналітичного й герменевтичного до міфопоетичного й інтертекстуального [4] - дозволяє говорити про формування в iï творчості специфічного метатексту, що подібний феномен фіксуємо в романістиці К. Гамсуна (А. Гурдуз), Л.-Ф. Селіна (А. Ретунських), Дари Корній (А. Гурдуз) чи новелістиці В. Стефаника (С. Хороб), причому за тими самими принципами. «Химерниця» становить собою властивий письменниці мелодраматичний роман зі слабко вираженою жанровою віднесеністю, в якому, подібно до «Грішниці» і «Кіл на воді», герої переживають граничні почуття, балансуючи між життям і смертю. Коли в «Грішниці» страждає самотня жінка-матір, а в «Колах на воді» - батько, то у «Химерниці» останній боїться втратити доньку через власну провину в минулому. Цим твором Олена Печорна продовжує ряд квазімістичних романів, де атмосфері ірраціонального сприяють характерні для іiі манери виражена тілесність і тенденція до системного уособлення природних явищ, об'єктів, абстракцій тощо. Уособлення в «Химерниці» вибірковіше й художній ефект його значно посилений порівняно 3 ранішими книгами авторки, де воно носило тотальний характер. Майже відсутні прийоми «оживлення», скажімо, у сценах діалогу персонажів «Химерниці» і переважно перенесені в описи душевного стану, пейзажу, інтер'єру. У такий спосіб мисткині вдається знівелювати в аналізованому тексті властиву попереднім книгам посилену сентиментальність, негативно оцінювану критикою [1].

Якщо в «Грішниці» чи «Колах на воді» переважають тематично близькі кластери уособлення: сонця, будинку тощо [2, с. 73-74], то в тексті 2020 р. на перший план виходять складніші структури постімпресіоністичної природи - «кільцеві елементи», що подібні рішення в творах М. Коцюбинського визначав Ю. Кузнецов [6, с. 226] i які в аналізованому романі сприяють концептуалізації низки явищ і понять. Зокрема, це такі, що корелюють із важливими кроками сюжету й створюють ефект композиційних кіл, яскраво виражені лейтмотивні імітації: а) оновлення («дерев'яні стіни лущились на сонці, наче міняли шкіру» [10, с. 7], «осінь скидала шкіру» $[10$, c. 269], «сад... роздягли миттєво. Він навіть не зрозумів, що сталося» [10, с. 285]); б) фігурально обіграних і символічних у сюжеті елементів уживання їжі та / чи смакових відчуттів (вітер «куштував на смак» [10, с. 13], ліс «ніби... 
проковтнув» [10, с. 7], «наче небо виплюнуло» [10, с. 12], «западає тиша - гірка до одуріння» [10, с. 364]; ніч «проковтнула» [10, с. 176] (зіставмо 3 виразом із «Кіл на воді»: «ніч пила самотність» [9, с. 19]), «героїня очиськами ліс ковтала» [10, с. 180]); в) специфічної анатомізації описуваних явищ, предметів, абстракцій тощо (вітер «терся прозорим черевом об землю» [10, с. 13], «сонна груша терлась мокрим черевом об димар» [10, с. 272], «піч вміла дихати» [10, с. 293], думки «гнізда вили» [10, с. 344], «вечір ворушився» [10, с. 56], «здичавіла тиша пише літописи» [10, с. 13] i т. ін.) часом із супровідним описом просторового пересування, що створює ефект уповільнення, меланхолії («немічний димар... сповз» [10, с. 7], «кільця диму... поповзли» [10, с. 64], «підповзали тумани» [10, с. 352]); г) тематично підкресленої тактильності, інтенційно піднесеного прагнення близькості й відчуття спорідненості («вітер до ночі тулився» [10, с. 277], «хатина притулилась» [10, с. 7], «сновидіння полохливо тулилися по кутках» [10, с. 292]; осінь і дощ «лізуть» «грітися» відповідно див.: [10, с. 269] і [10, с. 161]).

Традиційні ж для романістики Олени Печорної тематично споріднені кластери уособлення також присутні й формують своєрідне тло, на якому лейтмотивні імітації виглядають рельєфніше. Наведемо приклади таких тематичних сполучень: ліс дивився $[10$, с. 22], «все одно що підслухав» [10, с. 23], «ніби... проковтнув» $[10$, c. 7$]$; сосни «гомонять» $[10$, с. 8$]$, «колихали на кронах небо, що дитину в люльці» [10, с. 7]; яблука «цілувались з сонечком» [10, с. 285] (зіставмо в «Колах на воді»: «ніч безсоромно цілувалась 3 небом...» [9, с. 77]), «орхідея померла» $[10$, c. 272$]$; хатинка - «мов сварлива старенька» [10, с. 32]; будинок «сварився» $[10$, с. 272$]$, «не сподівався» [10, с. 271], «зрадів» [10, с. 273], «мирно сопів уві сні, іноді потягувався... йому снилася весна» [10, с. 277], «мерз навіть улітку» [10, с. 359] (порівняймо з раднішим романом: «будинок винувато нітився... і мовчав» [9, с. 18]). Варто назвати при цьому й інші асоціативні пасажі: вітер «завив, заголосив» $[10$, с. 94], «небо кричить» $[10$, с. 73], осінь «шипіла» $[10$, с. 269], «блукала... й дерлась у хату» [10, с. 271], ніч «продовжує верещати пронизливим сусідчиним голосом» [10, с. 304].

У майже наскрізь персоналізованій системі образів і мікрообразів «Химерниці» окреме місце належить концепту води, який отримує варіативний розвиток і поетика якого пронизує текст. Як і в «Колах на воді» чи «Фортеці для серця», вода тут жива, але вже не анатомізована [зіставмо: 9, с. 58; 9, с. 187; 9, с.271] і частіше змальовувана не власне як об'єкт, а в стилізованому описі процесів і станів. Персоналізовані, у першу чергу, дощ («бубонить» [10, с. 157], «облизував вікна» [10, с. 272], «лізе грітися» $[10$, с. 161]) і злива (вона «ніч викрала... в ліс завела... оточила стіною води» $[10$, с. 158]). Замість контекстно доречних «дощ» і «сльози» авторка, подібно до «Кіл на воді», часом уживає лексему «вода», евфемістично передаючи плач неба («небо заплакало» [10, с. 270], «плаче» [10, с. 162]): «з неба пішла вода» [10, с. 95], «побуде... під небом води» [10, с. 162] (порівняймо: «...3 неба нестримними потоками ллється вода...» [9, с. 21], «вода йшла з неба. Прозора і щемлива. Жива» [9, с. 186]).

Доповнюють водний диктат у романі (в якому навіть село, де відбуваються події, - Джерельне), відповідно стилізовані описи переживань і властивостей персонажів, дібрані як «компенсаційні» в контексті водної теми фразеологічні конструкції (аналогічний прийом застосовано в «Фортеці для серця» [4, с. 161-162]): «у грудях шторм» [10, с. 163], «я - мов перестояна вода» [10, с. 307], «у ті очі пірнути можна й не виплисти» [10, с. 163], з горя «не випливеш» [10, с. 165], «тепло аж струменить», «біль обмілів» [10, с. 367], «дівочі мрії струменять», «щастя - життєдайний океан» [10, с. 370], «хмільні спогади» [10, с. 20]; «...світ пішов за водою» [10, с. 272], «...пішла, мов у воду шубовснула» [20, с. 331]; «підігрівається чоловік (спиртним. А. Г.)» $[10$, с. 51$]$, «закипає, як... чайник» [10, с. 175]; «щось схоже на їдку кислоту випікає зсередини» [10, с. 373], «тіні минулого піднімаються на поверхню... якщо воду добряче скаламутити» [10, с. 211]. Наявні в тексті також асоціативні порівняльні звороти, наприклад: «Дорогу дорогою не назвеш, зате їх тутечки стільки, як судин, 
усе біжать, біжать, розходяться, сходяться, переплітаються» [10, с. 14]. Тлом при цьому стають різноманітні пов'язані з означенням рідини метафоричні описи: ніч «берегів не мала» [10, с. 272], «сутінки плавали лісом» [10, с. 56], «пливуть ті дорогиріки» [10, с. 157] тощо. У насиченому асоціативно-синестезійними сполуками тексті органічним $\epsilon$ передавання переживань із відповідним переходом ї в інших рецептивний регістр, скажімо: «страх... перетворюється на попіл» [10, с. 293], «обірвалась любов - як струна» [10, с. 145].

На відміну від «Кіл на воді», домінантна стихія води в «Химерниці» не має симетричного смислового кореляту (у романі 2013 р. це сонце і його метафоричне продовження - спека) й певно позбавлена амбівалентності [5, с. 18]; однак тут присутні традиційні для прози Олени Печорної специфічно осмислені концепти раю і «персоналізованого» пекла [10, с. 333] (аналогічний до останнього образ проходить уже в «Грішниці» [8, с. 20], адже рай на землі людьми знищено [9, с. 13]). Ці концепти сприяють органічному вплетенню в роман характерних для книг Олени Печорної й реалізованих у «Химерниці» вже на новому художньому рівні мотивів повернення й розплати за скоєне, провини і спокути, коли для духовного відродження-каяття людина змушена повернутися до себе справжньої, до вічних цінностей i, можливо, пожертвувати собою. Панівний образ водної стихії при цьому, піднесений у художньому світі письменниці, зокрема, як символ першооснови, жіночого начала [4, с. 162], і різноманітні пов'язані з рідиною мовні натяки сприяють інтенції мотиву повернення, а в системі мозаїчної структури міфопоетики роману реалізації міфу першотворення. Відповідно актуалізована роль у романі наскрізного для метапрози авторки концепту пам'яті.

У зв'язку зі сказаним варто підкреслити також важливість і невипадковість формування в тексті «Химерниці» концепту «крилатої» жінки. Суголосність духовного бачення Оленою Печорною образу сучасної українки, іпостась якої своєрідно концептуалізована саме в аналізованому романі, прикметна. Мисткиня своєрідно підхоплює й розвиває специфічну для української прози перших десятиліть XXI ст., гендерно мотивовану тезу про «крилатість» жінки, що такий образ уперше системно утвердився в метаромані Дари Корній [3] (водночас про крила людини загалом чи їх втрату в загальнофілософському сенсі згадується у вітчизняній літературі, переважно в поезії: це «Крила» Л. Костенко чи І. Драча; оповідання А. Дімарова, Дніпрової Чайки й ін.). У «Химерниці», III розділ якої названо «Безкрила», перед нами жінка - «пташка співоча» [10, с. 196], іiї руки, «наче крила» [10, с. 123], «3 неба впала моя дівчинка. Мороз крильця обпік» [10, с. 351]; «жінка має рухатися так, ніби має за плечима крила» [10, с. 221], «затікають спутані... крила» [10, с. 373], «головне - встигнути розправити крила» [10, с. 373]; «цілувала у маківку свою безкрилу (дівчинку. - А.Г.)» [10, с. 352]; «мати була нічною зозулею» $[10$, c. 346]. Акцентування крилатості жінки в «Химерниці» узгоджується з загальною художньою стратегією книги, підкресленою тілесністю роману й посилює резонансність звучання в ній концепту води. Крім того, людина як така в романі системно порівняна з рослинами та тваринами (сестра нагадує «живу кульбабку. Таке ж тонесеньке тіло - стеблинка й пухнаста голівка» [10, с. 266-267], люди нагадують «велетенських мурах» [10, с. 267], люд - «мов бджоли у вулику» [10, с. 279], хлопці «вистрибували, наче горобці» [10, с. 295] і под.), що органічно тяжінню Олени Печорної до переосмисленого в новому часі пантеїстичного змалювання людини в навколишньому світі й зближує іiі твір зі, скажімо, романами Ж. Жіоно («Спів світу», «Хай збудеться моя радість»), частково - Е. Золя («Земля»).

Висновки. Як видно зі сказаного, ключові імперативи прози письменниці й супровідні для них концепти й мотиви, закладені в ранніх «Грішниці» й «Колах на воді», доповнені, логічно розвинені й отримують у «Химерниці» нове звучання. Панівне жіноче начало, властиве художній (пантеїстичній) картині світу письменниці, в романі підкреслено домінантністю стихії води й відповідно оформленим ключовим концептом, подібно до «Кіл на воді». Реалізуючись через 
варіативну поетику (вже не анатомізована й амбівалентна, але жива вода оприявнює себе у стилізованих описах процесів і станів, зворотах персоніфікації й евфемізації, фразеологічних конструкціях тощо) і певно підпорядковуючи структуру твору - від лексичного до образного рівнів, - концепт води органічно взаємодіє аналогічними тематично спорідненими кластерами уособлення, лейтмотивними імітаціями 3 ефектом композиційних кіл, із концептами пам'яті, повернення, раю, пекла й под., сприяючи формуванню в романі міфопоетичної парадигми мозаїчного типу, властивої прозі Олени Печорної.

Роман «Химерниця», в такий спосіб, суголосний ідіостилю Олени Печорної й засвідчує іiі мистецьке зростання. Подальше системне дослідження романістики письменниці, зокрема в компаративному плані, є доцільним і продуктивним; ключові положення пропонованої статті можуть бути покладені в його основу й розвинені в контексті розгляду становлення нової української прози початку XXI ст.

\section{СПИСОК ВИКОРИСТАНИХ ДЖЕРЕЛ:}

1. Герасименко О. Про що мовчить вода? Всі книги. 2013. 3 вересня. URL: vsiknygy.net.ua/shcho_pochytati/30596 (дата звернення: 08.07.2017).

2. Гурдуз А. І. Концепт води в романі Олени Печорної «Кола на воді». Наукові праці Кам'янець-Подільського національного університету імені Івана Огієнка. Філологічні науки. Кам'янець-Подільський: Аксіома, 2015. Вип. 39. С. 72-75.

3. Гурдуз А.І. Метагероїня романів Дари Корній. Науковий вісник Миколаӥвського національного університету імені В.О. Сухомлинського. Філологічні науки: (літературознавство): зб. наук. пр. / за ред. О. С. Філатової. Миколаїв: МНУ ім. В. О. Сухомлинського, 2015. Жовтень. Вип. 2 (16). С. 61-67.

4. Гурдуз А.І. Міфопоетична парадигма в ідіостилі Олени Печорної: традиція і новаторство. Ідіостиль автора-твория: мовно-літературна парадигма: моногр. I за ред. О. С. Філатової. Миколаїв: ФОП Швець В. М., 2018. С. 145-168.

5. Гурдуз А. І. Міфопоетичне моделювання в прозі Олени Печорної й Алли Рогашко. Літератури світу: поетика, ментальність $і$ духовність: зб. наук. пр.; гол. ред. С. І. Ковпік. Кривий Ріг: Криворіз держ. пед. ун-т, 2017. Вип. 8. С. 15-23.

6. Кузнецов Ю. Імпресіонізм в українській прозі кінця XIX - початку XX ст.: (Проблеми естетики і поетики). Київ: Зодіак-ЕКО, 1995. 303 с.

7. Меншій А. «Напоєні красою слів твоїх...»: «школа» М. Коцюбинського в українському постімпресіонізмі: монографія. Миколаїв: Іліон, 2016. 580 с.

8. Печорна О. Грішниця; передм. М. Іванцової. 2-е вид., стереотип. Харків: Клуб сімейного дозвілля, 2013. 288 с.

9. Печорна О. Кола на воді; передм. Г. Пагутяк. Харків: Книжковий клуб «Клуб сімейного дозвілля», 2013. 288 с.

10. Печорна О. Химерниця: роман. Харків: Книжковий клуб «Клуб сімейного дозвілля», 2020. 384 с.

\section{REFERENCES}

1. Gerasimenko O. Pro scho movchit voda? VsI knigi. 2013. 3 veresnya. URL: vsiknygy.net.ua/shcho_pochytati/30596 (data zvernennya: 08.07.2017).

2. Gurduz A. I. Kontsept vodi v romanI Oleni PechornoYi «Kola na vodI». Naukovi pratsi Kam'yanets-Podilskogo natsionalnogo universitetu imeni Ivana Ogienka. Filologichni nauki. Kam'yanets-PodIlskiy: Aksioma, 2015. Vip. 39. S. 72-75.

3. Gurduz A.I. Metageroyinya romaniv Dari Korniy. Naukoviy visnik Mikolayivskogo natsionalnogo universitetu imeni V. O. Suhomlinskogo. Filologichni nauki: (literaturoznavstvo): zb. nauk. pr. / za red. O. S. Filatovoyi. Mikolayiv: MNU im. V. O. Suhomlinskogo, 2015. Zhovten. Vip. 2 (16). S. 61-67.

4. Gurduz A.I. Mifopoetichna paradigma v idiostili Oleni Pechornoyi: traditsiya i novatorstvo. Idiostil avtora-tvortsya: movno-literaturna paradigma: monogr. / za red. O. S. Filatovoyi. Mikolayiv: FOP Shvets V. M., 2018. S. 145-168. 
5. Gurduz A. I. Mifopoetichne modelyuvannya v prozi Oleni Pechornoyi y Alli Rogashko. Literaturi svitu: poetika, mentalnist i duhovnist: zb. nauk. pr.; gol. red. S. I. Kovpik. Kriviy Rig: Krivoriz derzh. ped. un-t, 2017. Vip. 8. S. 15-23.

6. Kuznetsov Yu. Impresionizm v ukrayinskIy prozI kintsya XIX - pochatku XX st.: (Problemi estetiki i poetiki). Kiyiv: ZodIak-EKO, 1995. 303 s.

7. MenshIy A. «Napoeni krasoyu sliv tvoyih...»: «shkola» M. Kotsyubinskogo v ukrayinskomu postimpresionizmi: monografIya. Mikolayiv: Ilion, 2016. $580 \mathrm{~s}$.

8. Pechorna O. Grishnitsya; peredm. M. Ivantsovoyi. 2-e vid., stereotip. Harkiv: Klub simeynogo dozvillya, 2013. $288 \mathrm{~s}$.

9. Pechorna O. Kola na vodi; peredm. G. Pagutyak. Harkiv: Knizhkoviy klub «Klub simeynogo dozvillya», 2013. $288 \mathrm{~s}$.

10. Pechorna O. Himernitsya: roman. Harkiv: Knizhkoviy klub «Klub simeynogo dozvillya», 2020. $384 \mathrm{~s}$.

Надійшла до редакиії 11 березня 2020 р. 